University of Nebraska - Lincoln DigitalCommons@University of Nebraska - Lincoln

Public Health Resources

Public Health Resources

$1-5-2017$

\title{
Repealing the ACA without a Replacement - The Risks to American Health Care
}

Barack Obama

President of the United States, contact@obamaoffice44.org

Follow this and additional works at: http://digitalcommons.unl.edu/publichealthresources

Part of the Bioethics and Medical Ethics Commons, Community Health Commons, Health and Medical Administration Commons, and the Life Sciences Commons

Obama, Barack, "Repealing the ACA without a Replacement — The Risks to American Health Care" (2017). Public Health Resources. 492.

http://digitalcommons.unl.edu/publichealthresources/492

This Article is brought to you for free and open access by the Public Health Resources at DigitalCommons@University of Nebraska - Lincoln. It has been accepted for inclusion in Public Health Resources by an authorized administrator of DigitalCommons@University of Nebraska - Lincoln. 


\title{
Repealing the ACA without a Replacement - The Risks to American Health Care
}

\author{
Barack H. Obama, J.D.
}

\section{T $T$ ealth care policy often shifts when the H country's leadership changes. That was true when I took office, and it will likely be true with President-elect Donald Trump. I am proud that}

my administration's work, through the Affordable Care Act (ACA) and other policies, helped millions more Americans know the security of health care in a system that is more effective and efficient. At the same time, there is more work to do to ensure that all Americans have access to high-quality, affordable health care. What the past 8 years have taught us is that health care reform requires an evidence-based, careful approach, driven by what is best for the American people. That is why Republicans' plan to repeal the ACA with no plan to replace and improve it is so reckless. Rather than jeopardize financial security and access to care for tens of millions of Americans, policymakers should develop a plan to build on what works before they unravel what is in place.

Thanks to the ACA, a larger share of Americans have health insurance than ever before. ${ }^{1}$ Increased coverage is translating into improved access to medical care - as well as greater financial security and better health. Meanwhile, the vast majority of Americans still get their health care through sources that predate the law, such as a job or Medicare, and are benefiting from improved consumer protections, such as free preventive services.

We have also made progress in how we pay for health care, including rewarding providers who deliver high-quality care rather than just a high quantity of care. These and other reforms in the
ACA have helped slow health care cost growth to a fraction of historical rates while improving quality for patients. This includes better-quality and lower-cost care for tens of millions of seniors, individuals with disabilities, and lowincome families covered by Medicare, Medicaid, and the Children's Health Insurance Program. And these benefits will grow in the years to come.

That being said, I am the first to say we can make improvements. Informed by the lessons we've learned during my presidency, I have put forward ideas in my budgets and a July 2016 article $^{2}$ to address ongoing challenges such as a lack of choice in some health insurance markets, premiums that remain unaffordable for some families, and high prescription-drug costs. For example, allowing Medicare to negotiate drug prices could both reduce seniors' spending and give private payers greater leverage. And I have al- 
ways welcomed others' ideas that meet the test of making the health system better. But persistent partisan resistance to the ACA has made small as well as significant improvements extremely difficult.

Now, Republican congressional leaders say they will repeal the ACA early this year, with a promise to replace it in subsequent legislation - which, if patterned after House Speaker Paul Ryan's ideas, would be partly paid for by capping Medicare and Medicaid spending. They have yet to introduce that "replacement bill," hold a hearing on it, or produce a cost analysis - let alone engage in the more than a year of public debate that preceded passage of the ACA. Instead, they say that such a debate will occur after the ACA is repealed. They claim that a 2- or 3-year delay will be sufficient to develop, pass, and implement a replacement bill.

This approach of "repeal first and replace later" is, simply put, irresponsible - and could slowly bleed the health care system that all of us depend on. (And, though not my focus here, executive actions could have similar consequential negative effects on our health system.) If a repeal with a delay is enacted, the health care system will be standing on the edge of a cliff, resulting in uncertainty and, in some cases, harm beginning immediately. Insurance companies may not want to participate in the Health Insurance Marketplace in 2018 or may significantly increase prices to prepare for changes in the next year or two, partly to try to avoid the blame for any change that is unpopular. Physician practices may stop investing in new approaches to care coordination if Medicare's
Innovation Center is eliminated. Hospitals may have to cut back services and jobs in the short run in anticipation of the surge in uncompensated care that will result from rolling back the Medicaid expansion. Employers may have to reduce raises or delay hiring to plan for faster growth in health care costs without the current law's cost-saving incentives. And people with preexisting conditions may fear losing lifesaving health care that may no longer be affordable or accessible.

Furthermore, there is no guarantee of getting a second vote to avoid such a cliff, especially on something as difficult as comprehensive health care reform. Put aside the scope of health care reform - the federal health care budget is $50 \%$ bigger than that of the Department of Defense. ${ }^{3}$ Put aside how it personally touches every single American - practically every week, I get letters from people passionately sharing how the ACA is working for them and about how we can make it better. "Repeal and replace" is a deceptively catchy phrase - the truth is that health care reform is complex, with many interlocking pieces, so that undoing some of it may undo all of it.

Take, for example, preexisting conditions. For the first time, because of the ACA, people with preexisting conditions cannot be denied coverage, denied benefits, or charged exorbitant rates. I take my successor at his word: he wants to maintain protections for the 133 million Americans with preexisting conditions. Yet Republicans in Congress want to repeal the individual-responsibility portion of the law. I was initially against this Republican idea, but we learned from Massachusetts that individual responsibility, alongside financial assistance, is the only proven way to provide affordable, private, individual insurance to every American. Maintaining protections for people with preexisting conditions without requiring individual responsibility would cost millions of Americans their coverage and cause dramatic premium increases for millions more. ${ }^{4}$ This is just one of the many complex trade-offs in health care reform.

Given that Republicans have yet to craft a replacement plan, and that unforeseen events might overtake their planned agenda, there might never be a second vote on a plan to replace the ACA if it is repealed. And if a second vote does not happen, tens of millions of Americans will be harmed. A recent Urban Institute analysis estimated that a likely repeal bill would not only reverse recent gains in insurance coverage, but leave us with more uninsured and uncompensated care than when we started. ${ }^{5}$

Put simply, all our gains are at stake if Congress takes up repealing the health law without an alternative that covers more Americans, improves quality, and makes health care more affordable. That move takes away the opportunity to build on what works and fix what does not. It adds uncertainty to lives of patients, the work of their doctors, and the hospitals and health systems that care for them. And it jeopardizes the improvements in health care that millions of Americans now enjoy.

Congress can take a responsible, bipartisan approach to improving the health care system. This was how we overhauled Medicare's flawed physician payment system less than 2 years ago. I 
will applaud legislation that improves Americans' care, but Republicans should identify improvements and explain their plan from the start - they owe the American people nothing less.

Health care reform isn't about a nameless, faceless "system." It's about the millions of lives at stake - from the cancer survivor who can now take a new job without fear of losing his insurance, to the young person who can stay on her parents' insurance after college, to the countless Americans who now live healthier lives thanks to the law's protections. Policymakers should therefore abide by the physician's oath: "first, do no harm."

The Massachusetts Medical Society copyright applies to the distinctive display of this New England Journal of Medicine article and not to the President's work or words.

Disclosure forms provided by the author are available at NEJM.org.

Mr. Obama is President of the United States.

This article was published on January 6 , 2017, at NEJM.org.

1. The economic record of the Obama administration: reforming the health care sys- tem. Washington, DC: Council of Economic Advisers, 2016.

2. Obama B. United States health care reform: progress to date and next steps. JAMA 2016;316:525-32.

3. The President's budget for fiscal year 2017. Washington, DC: Office of Management and Budget, 2016 (https://www .whitehouse.gov/omb/budget).

4. Options for reducing the deficit: 2017 to 2026. Washington, DC: Congressional Budget Office, 2016.

5. Blumberg LJ, Buettgens $M$, Holahan J. Implications of partial repeal of the ACA through reconciliation. Washington, DC: Urban Institute, 2016 (http://www.urban .org/research/publication/implications -partial-repeal-aca-through-reconciliation).

DOI: 10.1056/NEJMp1616577

Copyright (C) 2017 Massachusetts Medical Society. 